(UDAYANA MASTER LAW JOURNAL)

\title{
IDENTIFIKASI LINGKUP ISI DAN BATAS-BATAS OTONOMI DESA PAKRAMAN DALAM HUBUNGANNYA DENGAN KEKUASAAN NEGARA ${ }^{1}$
}

Oleh:

\section{Ketut Sudantra}

Ni Nyoman Sukerti

\author{
A.A. Istri Ari Atu Dewi
}

\begin{abstract}
This research objective is to study about autonomy concept in cutomary law society of desa pakraman in Bali. There are two main problems that will studied in this research, which are: (1) which powers are in scope of desa pakraman's autonomy?; (2) what are the boundaries of desa pakraman's autonomy in its relation with the sovereignty of Republic of Indonesia? Based on the research's result, can concluded that: First, it is concluded that the scope of desa pakraman's autonomy including: (1) sovereignty to make its own law; (2) sovereignty to govern itself; (3) sovereignty to make its own self-defense force; and (4) sovereignty to perform its own court. Secondly, it is concluded that, desa pakraman's autonomy isn't a autonomy without boundary, it is bound by conditions set by state's constitution, which is must on date and principles of Republic of Indonesia.
\end{abstract}

Kewyword: customary law society, desa pakraman, autonomy

\section{PENDAHULUAN}

\subsection{Latar Belakang Masalah}

Di awal tahun ini, tepatnya 15 Januari 2014, Presiden Susilo Bambang Yodoyono telah mengesahkan Undang-undang Nomor 6 Tahun 2014 tentang Desa (LNRI Tahun

Karya ilmiah ini merupakan hasil penelitian yang di biayai dari dana Dipa BLU Program Studi Magister(S2) Ilmu Hukum PPS UNUD dengan SK Rektor Nomor: 2116/UN.14.4/HK/2014, telah di presentasikan dalam seminar/FGD di Program Magister (S2) Ilmu Hukum pada tanggal 31 Oktober 2014

2 Penulis pertama dan kedua adalah Dosen pada Program Studi Magister (S2) Ilmu Hukum Program Pascasarjana Unud, sedangkan penulis ketiga adalah Mahasiswa Program Doktor Ilmu Hukum Program Pascasarjana Unud.
2014 Nomor 2; TLNRI Nomor 5495). Menurut undang-undang ini, Desa adalah desa dan desa adat atau yang disebut dengan nama lain, selanjutnya disebut Desa, adalah kesatuan masyarakat hukum yang memiliki batas wilayah yang berwenang untuk mengatur dan mengurus urusan pemerintahan, kepentingan masyarakat setempat berdasarkan prakarsa masyarakat, hak asal usul, dan/atau hak tradisional yang diakui dan dihormati dalam sistem pemerintahan Negara Kesatuan Republik Indonesia. 
Hal menarik yang patut mendapat perhatian dalam Undang-undang Desa adalah diaturnya secara khusus tentang keberadaan desa adat, yang diakui secara bersamaan dengan keberadaan desa. Walaupun undangundang tersebut tidak memberikan definisi secara spesifik tentang desa adat, tetapi dari karakter-karakter desa adat yang ditunjukkan oleh undang-undang tersebut, sangat jelas bahwa desa adat yang dimaksudkan dalam Undang-undang Desa adalah suatu kesatuan masyarakat hukum adat yang bersifat territorial.

Untuk Bali, konsep Desa Adat seperti yang dimaksud oleh Undang-undang Desa menunjuk kepada kesatuan masyarakat hukum adat teritorial yang saat ini disebut desa pakraman ${ }^{3}$, seperti yang diatur melalui Peraturan Daerah Provinsi Bali Nomor 3 tahun 2001 sebagaimana telah diubah dengan Peraturan Daerah Nomor 3 Tahun 2003 (selanjutnya disebut Perda Desa Pakraman). Berdasarkan peraturan sebelumnya, yaitu Peraturan Daerah Tingkat I Bali Nomor 06 Tahun 1986 istilah yang digunakan untuk menyebut kesatuan masyarakat hukum adat teritorial di Bali adalah desa adat.

Sejak dikeluarkannya Perda Desa Adat tahun 1986, secara yuridis di Bali diakui keberadaan dua sistem pemerintahan desa dalam satu wilayah desa, yaitu di

Dalam penelitian ini istilah "desa pakraman" dan istilah "desa adat" untuk pengertian sebagai suatu kesatuan masyarakat hokum adat di Bali, digunakan secara bergantian disesuaikan dengan istilah asli yang digunakan oleh sumber yang dikutip, terutama ketika menyangkut nama desa. Misalnya sumber aslinya menggunakan istilah Awig-awig Desa Adat Bugbung" atau Awig-awig Desa Pakraman Gadungan” satu sisi terdapat pemerintahan desa yang menyelenggarakan fungsi administrasi pemerintahan negara (disebut: desa dinas) dan di sisi lain terdapat pemerintahan desa yang menyelenggarakan fungsi sosial religius (disebut: desa adat; sekarang desa pakraman). Dua bentuk desa tersebut berada dalam kondisi ko-eksistensi, samasama diakui baik secara sosiologis maupun yuridis. Pemerintahan desa dinas adalah organisasi pemerintahan negara dalam satu wilayah desa yang dibentuk dengan prosedur dan menurut persyaratan-persyaratan yang diatur oleh peraturan perundang-undangan, khususnya undang-undang yang mengatur tentang pemerintahan daerah (yang di dalamnya juga mengatur tentang desa). Berbeda dengan desa dinas, desa pakraman adalah kesatuan masyarakat hukum adat yang terbentuk atau dibentuk berdasarkan prakarsa masyarakat yang bersangkutan sesuai tradisi yang telah lama hidup, di mana mereka menjadi satu kesatuan karena menempati suatu wilayah (palemahan) yang sama dalam suatu ikatan tempat persembahyangan bersama (parhyangan) yang disebut kahyangan desa atau kahyangan tiga. Dua bentuk pemerintahan desa tersebut tidak mempunyai hubungan struktural, tetapi selama ini berjalan beriringan dalam hubungan fungsional yang harmonis karena selalu berkordinasi dalam menyelenggarakan kehidupan masyarakat di desa.

$$
\text { Berlakunya Undang-undang }
$$

Desa, akan sangat berpengaruh terhadap eksistensi desa di Bali yang dualistis di atas. Penjelasan Pasal 6 Undang-undang Desa 
mengisyaratkan bahwa Bali harus memilih salah satu bentuk desa, sebabUndang-undang Desa menghendaki dalam satu wilayah desa hanya terdapat Desa atau Desa Adat. Dalam wacana yang berkembang, bagi Bali kini tersedia pilihan-pilihan (opsi) berkaitan dengan eksistensi dua bentuk desa tersebut di atas, yaitu (1) tetap mempertahankan kondisi yang ko-eksistensi dua desa seperti yang terjadi saat ini; (2) menggabungkan dua bentuk desa tersebut; (2) memilih salah satu diantaranya sebagaimana yang dikehendaki oleh Penjelasan Pasal 6 Undang-undang Desa $^{4}$. Memilih salah satu opsi di atas bukanlah suatu pekerjaan yang mudah sehingga apapun putusan mengenai pilihan yang diambil harus berdasarkan pemikiran yang kritis dan mendalam. Segala aspek yang berkaitan dengan desa di Bali perlu mendapat perhatian serius.

Salah satu aspek desa pakraman yang penting mendapat perhatian adalah aspek otonomi yang dimilikinya. Sebagai suatu kesatuan masyarakat hukum adat, desa pakraman mempunyai otonomi asli yang tidak boleh terganggu (dikurangi, apalagi dihapuskan) oleh apapun putusan yang diambil nanti oleh pengambil kebijakan mengenai pilihan atas opsi-opsi di atas. Oleh karena itu, penting dipastikan konsep otonomi desa pakraman yang selama ini hidup dan diakui, terutama menyangkut

Opsi-opsi ini pernah didiskusikan dalam Focus Group Discusion (FGD) yang diselenggarakan oleh Bappeda Provinsi Bali Bali tanggal 15 April 2014. Lihat: Pedoman Diskusi Kelompok Menyikapi Undangundang Nomor 6 Tahun 2014 tentang Desa yang dilaksanakan oleh Bappeda Provinsi bali, 15 April 2014 lingkup dan batasannya sehingga pengambil kebijakan memahami dan dapat menjaganya. Sesungguhnya, secara substansial otonomi menyangkut seperangkat hak atau kekuasankekuasaan terkait dengan pemerintahan sendiri atau pengurusan urusan rumah tangga sendiri. Penting diidentifikasi: lingkup isi kekuasaan-kekuasaan desa pakraman yang masih hidup dan diakui keberadaannya saat ini. Berhubung desa pakraman adalah bagian dari Negara Kesatuan Republik Indonesia, maka penting pula dikaji hubungan otonomi desa pakraman tersebut dengan kekuasaan negara, sehingga dapat diidentifikasi batasan-batasannya. Berdasarkan latar belakang pemikiran tersebut di atas, maka penelitian ini dilakukan melalui suatu kajian yang bersifat teoritis dan normatif.

\subsection{Rumusan Masalah}

Berdasarkan latar belakang di atas, berikut ini dapat dirumuskan permasalahan yang akan diteliti, yaitu:

1. Apa kekuasaan-kekuasaan yang menjadi lingkup isi otonomi desa pakraman?

2. Apa batas-batas otonomi desa pakraman dalam hubungannya dengan kekuasan Negara Kesatuan RI ?

\section{METODE PENELITIAN}

\subsection{Jenis Penelitian dan Pendekatan}

Penelitian ini bertujuan mengidentifikasi lingkup isi otonomi desa pakraman dan batas-batasnya dalam hubungannya dengan kekuasaan negara. Hubungan tersebut dikaji berdasarkan 
norma-norma hukum yang berlaku, baik norma-norma hukum dalam komunitas adat itu sendiri maupun norma hukum negara. Dengan demikian, penelitian ini termasuk jenis penelitian hukum normatif. Pendekatan yang digunakan adalah pendekatan konseptual, di samping pendekatan perundangundangan (untuk hukum negara) dan pendekatan awig-awig (untuk hukum adat). Pendekatan konseptual diperlukan untuk membangun argumentasi mengenai konsep otonomi desa pakraman sehingga dapat digunakan untuk mengidentifikasi lingkup isi dan batas-batas otonomi desa pakraman tersebut.

\subsection{Jenis dan Sumber Bahan Penelitian}

Dalam penelitian ini, bahan penelitian yang digunakan meliputi bahan hukum (primer dan sekunder) dan bahan-bahan non hukum. Bahan hukum primer yang bersumber dari peraturan hukum negara meliputi peraturan perundang-undangan yang relevan, sesuai hirarkinya mulai dari Undang-undang Dasar Negara Republik Indonesia Tahun 1945, undang-undang, peraturan pemerintah, sampai peraturan daerah. Sedangkan bahan hukum primer yang bersumber dari hukum adat adalah awig-awig desa pakraman sampel dari semua kabupaten/kota di Bali. Bahan hukum sekunder yang digunakan dalam penelitian ini adalah semua literatur-literatur hukum yang relevan, mulai dari buku teks, laporan penelitian, artikel dalam jurnal hukum, sampai pada kamus hukum.

Bahan non-hukum, kamus Bahasa Bali, diperlukan untuk menjelaskan (termasuk menerjemahakn) istilah-istilah dan konsepkonsep yang terdapat dalam awig-awig desa pakraman yang umumnya ditulis dalam Bahsa Bali.

\subsection{Teknik Pengumpulan Bahan Hukum}

Bahan-bahan penelitian yang digunakan dalam penelitian ini dikumpulkan dengan teknik studi dokumen. Informasi yang relevan dari bahan-bahan penelitian di atas diphotocopy dan atau dicatat dalam kertas-kertas lepas dan selanjutnya disimpan dalam file dokumen di komputer. Catatancatatan dibuat dengan mencantumkan materi (informasi) yang dikutip serta idetitas lengkap sumber yang dikutip (literatur: nama penulis, judul karangan, nama, alamat dan tahun terbit serta halaman yang dikutip; peraturan: pasal, nama peraturan, lembaran negara/daerah).

\subsection{Pengolahan da Analisis Bahan Hukum}

Pengolahan terhadap informasi yang diperoleh dari bahan-bahan penelitian di atas dilakukan melalui proses kwalifikasi dan sistematisasi bahan-bahan hukum. Setelah tersusun secara sistematis sesuai kwalifikasi yang telah ditetapkan sebelumnya, informasi-informasi tersebut selanjutnya dianalisis dengan menggunakan teknikteknik penalaran dan argumentasi hukum (legal reasoning and legal argumenttion) yang relevan. Pada tahap akhir, keseluruhan hasil penelitian disajikan secara deskreptif analitis. 


\section{HASIL DAN PEMBAHASAN}

\subsection{Konsep dan Landasan Yuridis Otonomi Desa Pakraman}

Secara legal formal, konsep dan landasan yuridis otonomi desa pakraman dapat ditemukan dalam Pasal 1 Peraturan daerah Nomor 1 Tahun 2001. Walaupun pasal tersebut tidak menyebut secara ekplisit istilah "otonomi", tetapi dengan pernyataan bahwa "desa pakraman adalah...kesatuan masyarakat hukum adat...yang berhak mengurus rumah tanggnya sendiri" sudah dapat ditafsirkan bahwa Negara -melalui Perda Desa Pakraman -telah mengakui bahwa desa pakraman adalah kesatuan masyarakat hukum adat yang mempunyai otonomi. Lagi pula, dalam penjelasan Perda Desa Pakraman, secara tidak langsung frasa "berhak mengurus rumah tanganya sendiri” disamakan maknanya dengan istilah "otonomi". Di dalam penjelasan terhadap PerdaDesaPakraman,istilah"otonomi"dalam kontek otonomi desa pakraman disebutkan dua kali, yaitu pada penjelasan umum angka 4 dan penhjelasan umum angka 9. Dalam penjelasan umum angka 4 disebutkan bahwa "Landasan pemikiran pengaturan mengenai desa pakraman adalah keanekaragaman, partisipasi, otonomi asli (cetak miring dari peneliti), demokratisasi dan pemberdayaan krama desa". Sedangkan dalam penjelasan umum angka 9 dikemukakan bahwa "... peraturan daerah ini mengukuhkan otonomi desa pakraman"(cetak miring dari peneliti).

Dengan mengacu pada penafsiran otentik dalam penjelasan Perda Desa Pakraman, maka dapat disimpulkan bahwa otonomi desa pakraman secara konseptual mengandung makna sebagai hak atau kekuasaan desa pakraman dalam mengurus rumah tanganya sendiri. Dalam mengurus rumah tangganya sendiri tersebut, desa pakraman mempunyai seperangkat kekuasaan tertentu yang merupakan isi otonomi desa pakraman itu sendiri. Seperti yang dikemukakan oleh $\mathrm{C}$. van Vollenhoven dalam Ajaran Catur Praja, otonomi mencakup keekuasaan-kekuasaan (1) membentuk perundang-undangan sendiri(zelfwetgeving), (2) melaksanakan sendiri (zelffuitvoering), (3) melakukan tugas kepolisian sendiri (zelfpolitie), dan melakukan peradilan sendiri (zelfrechtspraak) $)^{5}$. Apa wujud kekuasaankekuasaan tersebut dan bagaimana kekuasaan-kekuasaan tersebut dilaksanakan oleh desa pakraman pada gilirannya akan diuraikan secara khusus dan lebih mendalam pada pembahasan berikutnya.

Pengakuan atau pengukuhan otonomi desa pakraman melalui Perda Desa Pakraman dapat dipandang sebagai derivasi langsung ketentuan Pasal 18B ayat (2) UUDNRI Tahun 1945 yang memberikan pengakuan terhadap eksistensi kesatuan masyarakat hukum adat beserta hak-hak tradisionalnya. Seperti diketahui, pasal tersebut mengamanatkan bahwa pengakuan dan pengormatan terhadap kesatuan masyarakat hukum adat mesti dituangkan dalam undang-undang. Undang-

Amrah Muslimin, 1986, Aspek-aspek Hukum Otonomi Daerah, Bandung: Alumni, hlm. 6. Lihat pula: Panitia Ad Hoc.I DPD RI, 2009 "Naskah Akademik Rancangan Undang-undang tentang Perlindungan Masyarakat Adat", Dewan Perwakilan Daerah Republik Indonesia, Juni 2009, hlm. 50. 
undang yang dimaksudkan oleh Pasal 18B ayat (2) tersebut tidak saja meliputi undangundang yang secara khusus mengatur tentang kesatuan masyarakat hukum adat ataupun undang-undang sektoral lainnya ${ }^{6}$ - seperti Undang-undang Agraria, Undang-undang Kehutanan, dan lain-lain - melainkan meliputi juga peraturan perundang-undangan lainnya (undang-undang dalam arti luas) termasuk di dalamnya peraturan daerah ${ }^{7}$. Dengan demikian, tidak diragukan lagi bahwa otonomi desa pakraman mempunyai landasan yang kuat, di samping bersumber dari kodratnya sendiri (otonomi asli) juga diakui eksistensinya dalam peraturan perundang-undangan Republik Indonesia.

\subsection{Lingkup Isi Otonomi Desa Pakraman}

\subsubsection{Kekuasaan untuk membentuk hukumnya sendiri.}

Desa pakraman sebagai kesatuan masyarakathukum adat yang bersfat teritorial mempunyai kekuasaan dalam membentuk tatanan hukumnya sendiri yang bersendikan kepada adat-istiadat (dresta) setempat. Tatanan hukum yang berlaku bagi warga desa

Bandingkan dengan: Mahkamah Konstitusi Republik Indonesia, Putusan Perkara Nomor 007/PUU-III/2005 dalam Perkara Pengujian Undang-undang Republik Indonesia Nomor 40 Tahun 2004 tentang Sistem Jaminan Sosial Nasional terhadap Undang-Undang Dasar Negara Republik Indonesia Tahun 1945, hlm. 268

7 Jimly Assiddiqie, 2006, Perihal Undang-undang, Konstitusi Press, Jakarta, hlm. 36; Lihat juga: Gede Marhaendra Wija Atmaja, "Politik Pluralisme Hukum dalam Pengakuan Kesatuan Masyarakat Hukum Adat dengan peraturan Daerah", Disertasi, (Malang: Program Doktor Ilmu Hukum Universitas Bwawijaya, 2012), hlm. 281 pakraman ini lazim disebut dengan istilah awig-awig desa pakraman. Tjok Istri Putra Astiti menyatakan bahwa awig-awig adalah patokan-patokan tingkah laku, baik tertulis maupun tidak tertulis yang dibuat oleh masyarakat yang bersangkutan, berdasarkan rasa keadilan dan kepatutan yang hidup dalam masyarakat, dalam hubungan antara krama (anggota desa pakraman) dengan Tuhan, antar sesama krama, maupun krama dengan lingkungannya ${ }^{8}$.

Sebagai istilah teknis yuridis, istilah awig-awig mulai digunakan dalam Peraturan Daerah Provinsi Daerah Tingkat I Bali Nomor 6 Tahun 1986 tentang Kedudukan, Fungsi, dan Peranan Desa Adat sebagai Kesatuan masyarakat Hukum Adat dalam Provinsi Bali. Dalam peraturan daerah ini, istilah yang digunakan adalah "awig-awig desa adat" (Pasal 7-Pasal9), tetapi peraturan daerah ini tidak memberikan perumusan pengertian awig-awig desa adat secara difinitif. Peraturan Daerah Nomor 6 Tahun 1986 dapat dikatakan sebagai produk hukum daerah pertama yang mengatur keberadaan desa adat (sekarang: desa pakraman) di Bali. Difinisi konsep dari awig-awig desa pakraman baru dapat ditemukan setelah terbitnya Perda Desa Pakraman, yang dalam Pasal 1 angka 11 menyatakan bahwa:

"Awig-awig adalah aturan yang dibuat oleh krama desa pakraman dan atau krama banjar pakraman yang dipakai sebagai pedoman dalam pelaksanaan

Tjok Istri Putra Astiti, 2005, Pemberdayaan Awigawig Menuju Ajeg Bali, Lembaga Dokumentasi dan Publikasi Fakultas Hukum Universitas Udayana, hlm. 19 
Tri Hita Karana sesuai dengan desa mawacara dan dharma agama di desa pakraman/banjar pakraman masingmasing"

Ketentuan yang menyatakan bahwa awig-awig desa pakraman dibuat oleh krama desa sudah ditentukan dalam Pasal 7 Peraturan Daerah Nomor 6 Tahun 1986, tetapi dalam peraturan daerah tersebut tidak ditegaskan tentang bagaimana cara krama desa membuat awig-awig tersebut. Ketentuan lebih tegas tentang mekanisme pembuatan awig-awig ditemukan dalam Paal 12 Perda Desa Pakraman yang menyatakan bahwa "Awig-awig desa pakraman dibuat dan disahkan oleh krama desa pakraman melalui paruman desa pakraman". Dengan demikian, maka dapat diketahui bahwa lembaga yang berwenang membentuk awig-awig desa pakraman adalah paruman desa pakraman. Yang dimaksud dengan paruman desa pakraman adalah musyawarah krama desa pakraman yang tujuannya untuk memusyawarahkan dan mengambil keputusan terhadap hal-hal tertentu yang berhubungan dengan desa pakraman.

\subsubsection{Kekuasaan melaksanakan pemerintah-} an sendiri

Kekuasaan lain yang dimiliki oleh desa pakraman sebagai kesatuan masyarakat hukum adat di Bali adalah kekuasaan melaksanakan sendiri pemerintahannya. I Ketut Wirta Griadhi menyebut kekuasaan ini sebagai kekuasaan untuk menyelenggarakan kehidupan organisasi desa pakraman. Sejalan dengan sifat organisasi desa pakraman, Griadhi kemudian menyebutkan bahwa penyelenggaraan kehidupan oraganisasi desa pakraman menyangkut kekuasaankekuasaan:

(1) Kekuasaan dalam bidang organisatoris, meliputi kekuasaan untuk mengatur kehidupan desa sebagai suatu organisasi, antara lain menyangkut pembentukan pengurus desa pakraman, pembentukan aturan-aturan, penentuan keanggotan desa, dan lain-lain;

(2) kekuasaan bidang sosial ekonomi, yang menyangkut hubungan-hubungan antara anggota kelompok masyarakat, termasuk pula mengenai kekayaan desa; dan

(3) kekuasaan dalam bidang religius yang menyangkut hak dan kewajiban warga desa sebagai individu maupun kesatuan terhadap tempat pemujaan dalam desa. ${ }^{9}$

Secara operasional kekuasaan pemerintahan di desa pakraman diselenggarakan oleh pengurus desa yang disebut prajuru desa pakraman (paduluan atau dulu desa) ${ }^{10}$. Perda Desa Pakraman secara jelas menyebutkan bahwa prajuru inilah sebagai "pemimpin" desa pakraman dengan tugas-tugas sebagai berikut (Pasal 8):

I Ketut Wirta Griadhi, 1991, "Peranan Otonomi Desa Adat dalam Pembangunan”, Majalah Ilmiah Fakultas Hukum Kertha Patrika, No. 54 Tahun XVII., hlm. 58.

10 I Ketut Sudantra dan Wayan P. Windia, 2012, Sesana Prajuru Desa, Tatalaksana Pimpinan Desa Adat di Bali, Udayana University Press, Denpasar, hlm. 28. 

a. Melaksanakan awig-awig desa pakraman;

b. Mengatur penyelenggaraan upacara keagamaan di desa pakraman;

c. Mengusahakan perdamaian dan penyelesaian sengketa-sengketa adat;

d. Mewakili desa pakraman dalam bertindak untuk melakukan perbuatan hukum baik di dalam maupun di luar peradilan atas persetujuan paruman desa;

e. Mengurus dan mengatur pengelolaan harta kekayaan desa pakraman;

f. Membina kerukunan umat beragama dalam wilayah desa pakraman.

\subsubsection{Kekuasaan melakukan tugas} pengamanan sendiri

Desa pakraman juga mempunyai kekuasaan untuk melakukan tugas pengamanan sendiri, yang secara operasional dilaksanakan oleh Pacalang ${ }^{11}$. Menurut rumusan Semiloka Pecalang yang diselenggarakan di Ubud, Gianyar tahun 2001, pacalang adalah satuan tugas (satgas) keamanan tradisional masyarakat Bali yang mempunyai wewenang untuk menjaga keamanan dan ketertiban wilayah baik di tingkat banjar pakraman dan atau wilayah desa pakraman ${ }^{12}$

11 Dalam penelitian ini istilah "pacalang" dan istilah "Pecalang" yang mempunyai arti yang sama, kadangkadang digunakan secara bergantian disesauikan dengan istilah yang digunakan oleh sumber aslinya.

12 Wayan P. Windia, 2004, "Sesana dan Busana Pecalang", dalam Wayan P. Windia (ed), Pecalang Perangkat Keamanan Desa Pakraman di Bali, Lembaga Pengabdian Kepada Masyarakat (LPM) Universitas Udayana, hlm. 99.
Keberadan pacalang diatur dalam Perda Desa Pakraman, yaitu pada Pasal 17 yang menentukan sebagai berikut:

(1) Keamanan dan ketertiban wilayah desa pakraman dilaksanakan oleh pacalang.

(2) Pacalang melaksanakan tugastugas pengamanan dalam wilayah desa pakraman dalam hubungan pelaksanaan tugas adat dan agama.

(3) Pacalang diangkat dan diberhentikan oleh desa pakraman berdasarkan paruman desa.

Walaupun Perda Desa Pakraman tidak menegaskan difinisi pacalang, tetapi dari ketentuan di atas dapat dipahami bahwa yang dimaksud dengan pacalang adalah petugas yang diangkat oleh desa pakraman untuk melaksanakan fungsi untuk menjaga keamanan dan ketertiban wilayah desa pakraman dalam hubungan pelaksanaan tugas adat dan agama.

Dari hasil penelusuran terhadap awigawig desa pakraman diBali, belum ditemukan awig-awigdesapakramanyang secaraspesifik mengatur tentang Pacalang, baik awigawig yang dibuat sebelum atau pun setelah berlakunya Perda Desa Pakraman. Namun demikian, hal ini tidak dapat menegasikan kekuasaan desa pakraman dalam menjaga keamanan wilayahnya, sebab keberadaan pacalang sebagai petugas kemananan desa pakraman adalah suatu realitas yang tak terbantahkan. Dalam setiap aktivitas desa pakraman yang melibatkan banyak orang (massa) baik dalam ritual-ritual keagamaan 
(yadnya) di pura atau pun aktivitas sosial lainnya, pada umumnya pacalang selalu ada di sana untuk menjaga keamanan dan ketertiban. Pada desa-desa pakraman di daerah perkotaan yang banyak penduduk pendatangnya (banyak rumah kost) pacalang secara rutin melakukan pengawasan dan pemeriksaan penduduk pendatang melalui inpeksi mendadak (sidak).

Kalau di dalam awig-awig desa pakraman tidak diatur eksistensi pacalang, bagaimana menjelaskan landasan legal keberadaan dan aktivitas-aktivitas pacalang yang selama ini berlangsung?. Pertanyaan ini dapat ditemukan jawabannya dalam hasil penelitian yang dilakukan oleh A.A. Ketut Sukranata dan Anak Agung Istri Ari Atu Dewi, tahun 2005. Dalam penelitian dilakukan di Desa Pakraman Kedonganan (Badung) tersebut ditemukan fakta bahwa di desa pakraman ini pacalang tidak diatur di dalam awig-awig desa pakraman, melainkan diatur melalui Pararem Desa Pakraman Kedonganan Indik Pecalang (Keputusan Desa Pakraman Kedonganan tentang Pacalang) yang dibuat tahun 2003. Pararem desa pakraman adalah keputusankeputusan paruman (musyawarah) kerama desa pakraman yang mempunyai kekuatan mengikat sama seperti awig-awig. Banyak kepututusan-keputusan paruman desa pakraman yang tidak dituangkan dalam bentuk pararem tertulis, tetapi Pararem Desa Pakraman Kedonganan Indik Pecalang dibuat secara tertulis dan sistematis. Pararem ini mengatur secara lengkap dan rinci kelembagaan pacalang, mulai dari kedudukan, struktur, tatacara pengangkatan, dan tugas-tugas pacalang ${ }^{13}$. Di samping dari hasil penelitian A.A. Sukranata dan Anak Agung Istri Ari Atu Dewi di atas, peneliti juga menemukan pararem-pararem serupa di Desa Pakraman Jimbaran (Pararem tahun 2003); Desa Pakraman Pecatu (Pararem tahun 2005), Desa Pakraman Unggasan (Pararem tahun 2006), dan di Desa Pakraman Kapal (Pararem tahun 2007).

3.2.4.Kekuasaan melaksanakan peradilan sendiri

Awig-awig desa pakraman mengatur mekanisme-mekanismepenyelesaianperkara yang terjadi di wilayah desa pakraman. Mekanisme-mekanisme tersebut tidak lain adalah suatu fungsi peradilan yang terwujud dari kekuasaan mengadili yang dimiliki oleh kesatuan masyarakat hukum adat desa pakraman. Mekanisme penyelesaian perkara tersebut bahkan mendapatkan forsi khusus di dalam awig-awig desa pakraman karena diatur dalam bab tersendiri yang diberi judul: Wicara lan Pamidanda (Masalah/Perkara dan Sanksi) ${ }^{14}$.

13 A.A. Ketut Sukranata dan Anak Agung Istri Ari Atu Dewi, 2005, "Eksistensi Pecalang Menurut Awigawig Desa Pakraman (Studi Kasus Tetrhadap Awig-awig Desa Pakraman Kedonganan, Kuta), Pusat Studi Hukum Adat Universitas Udayana, hlm. 36.

14 I Ketut Sudantra, et. all., 2013, "Pengaturan Peradilan Adat dalam Awig-awig Desa Pakraman: Studi Pendahuluan tentang Eksistensi Peradilan Adat dalam Kesatuan Masyarakat Hukum Adat Desa Pakraman", Program Studi Magister (S2) Ilmu Hukum Pascasarjana Universitas Udayana, Denpasar, hlm. 45. 
Menurut awig-awig desa pakraman, aktivitas penyelenggaraan peradilan dilaksanakan oleh prajuru desa pakraman secara berjenjang. Apabila perkara itu terjadi di tingkat banjar ${ }^{15}$, maka perkara tersebut diselesaikan oleh prajuru banjar dipimpin oleh Kelihan Banjar. Apabila perkara tersebut tidak dapat diselesaikan di tingkat banjar dengan mekanisme yang tersedia di tingkat banjar, maka penyelesaian dilakukan di tingkat desa oleh prajuru desa dipimpin oleh Bendesa. Dalam awig-awig tidak ditemukan pengaturan yang jelas mengenai prosedurprosedur penyelenggaraan peradilan ${ }^{16}$, tetapi berdasarkan temuan penelitian yang dilaksanakan oleh Tim Peneliti dari LBH Bali diketahui bahwa kekuasaan peradilan tersebut dilaksanakan oleh Prajuru secara musyawarah dalam suatu sangkepan (paruman) seusai jenjangnya, yaitu melalui paruman banjar dalam hal penyelesaian perkara terjadi di tingkat banjar atau paruman desa dalam hal perkara diselesaikan di tingkat desa pakraman ${ }^{17}$.

Untuk lebih menegaskan kembali bahwa desa pakraman memiliki kekuasaan dalam melaksanakan peradilan sendiri, berikut ini dikutip Pawos 72 Awig-awig Desa Adat Batumulapan, Nusa Penida, Kabupaten Klungkung, yang dibuat tahun 1998. Ayat 1 Pawos 78 tersebut dengan tegas

15 Menurut Pasal 1 angka 5 Perda Desa Pakraman, banjar adalah kelompok masyarakat yang merupakan bagian dari desa pakraman.

16 I Ketut Sudantra et.all., op.cit., hlm. 61.

17 Tim Peneliti LBH Bali, 2005, Peradilan Desa, Alternatif Penyelesaian Sengketa, LBH Bali-Yayasan Kemala, hlm. 128-130. menyatakan bahwa: "Banjar/Desa Adat wenang niwakang pamidanda ring warga sane sisip", yang artinya bahwa banjar atau desa pakraman berwenang (mempunyai kekuasaan) menjatuhkan sanksi kepada warga yang bersalah ${ }^{18}$. Penjatuhan sanksi adalah bagian dari suatu proses dalam mekanisme peradilan. Dengan demikian maka tidak diragukan lagi bahwa desa pakraman memiliki kekuasan melaksanakan peradilan sendiri (zelfrechtspraak)

\subsection{Batasan Otonomi Desa Pakraman dalam Kontek Kekuasaan Negara}

Dikaji dari perspektif teori Sally Falk Moore tentang lapangan sosial semi otonom (semi-outomous social field), maka dapat diidentifikasi bahwa desa pakraman termasuk sebagai suatu kelompok sosial yang semi-otonom. Mengenai kekuasaan kelompok sosial yang semi-otonom tersebut, Moore menyatakan bahwa:

"The semi-autonomous social field has rule making capacities, and the means to induce or coerce compliance; but it is simultaneously set in larger social matrix which can, and does, affect and invade it, sometimes at the invitation of persons inside it, sometimes at its own instance ${ }^{\prime 19}$

\footnotetext{
Hampir semua awig-awig desa pakraman yang diteliti memuat ketentuan seperti dalam Pawos 78 Awig-awig Desa Adat Batumulapan ini. Awig-awig Desa Adat Bugbug, memuat ketentuan tersebut dalam Pawos 81; Awig-awig Desa Adat Gebog Satak Tiga Buungan memuat dalam Pawos 70; Awig-awig Desa Adat Belega memuat dalam Pawos 83; dan lain-lain.

19 Sally Falk Moore, 1978, Laws as Process, An Anthropological Approach, Routledge \& Kegal Paul, London,Boston, Melbourne and Henly, hlm. 56.
} 
Berdasarkan konstruksi teori Sally Falk Moore ini, maka dapat digambarkan bahwa desa pakraman adalah kelompok sosial semi-otonom yang berada dalam lingkup kelompok sosial yang lebih luas, yaitu organisasi negara yang bernama Negara Kesatuan Republik Indonesia. Di satu sisi, desa pakraman sebagai suatu kesatuan masyarakat hukum adat yang semi-otonom, mempunyai kapasitas untuk membuat aturan hukum sendiri (awig-awig) berdasarkan adat istiadat setempat, memiliki pula sarana yang dapat memaksa seseorang untuk mematuhi aturan yang dibuatnya itu. Pada saat yang bersamaan, Negara Kesatuan Republik Indonesia yang menguasai desa pakraman itu sendiri dapat memengaruhi kekuasaankekuasaan yang dimiliki oleh desa pakraman tersebut.

Analisis di atas sesuai dengan ketentuan Pasal 18B ayat(2)UUDNRI Tahun 1945 yang menjadi landasan konstitusional keberadaan desa pakraman. Selengkapnya pasal tersebut menyatakan sebagai berikut:

"Negara mengakui dan menghormati kesatuan-kesatuan masyarakat hukum adat beserta hak-hak tradisionalnya sepanjang masih hidup dan sesuai dengan perkembangan masyarakat dan prinsip Negara Kesatuan Republik Indonesia yang diatur dalam undangundang"

Pengakuan bersyarat terhadap kesatuan masyarakat hukum adat desa pakraman tersebut sekaligus menunjukkan kekuasaan negara terhadap keberadaan desa pakraman, yaitu Negara mempunyai kekuasaan mengakui atau tidak mengakui desa pakraman dan hak-hak otonominya. Apabila otonomi desa pakraman memenuhi persyaratan-persyaratan yang disebutkan dalam Pasal 18B ayat (2) di atas, maka negara dapat mengakui dan menghormatinya. Sebaliknya, apabila dalam pandangan negara otonomi desa pakraman tersebut tidak memenuhi syarat-syarat tersebut maka negara mempunyai kekuasaan untuk tidak mengakuinya.

Pengakuan bersyarat terhadap desa pakaman sekaligus mempunyai makna bahwa otonomi desa pakraman bukanlah otonomi mutlak tanpa batas. Melalui konstitusi, Negara telah memberikan syaratsyarat bagi otonomi desa pakraman. Otonomi desa pakraman diakui oleh Negara apabila di dalam kenyataan kekuasaan-kekuasaan yang menjadi isi dari otonomi desa pakraman tersebut memang benar-benar masih hidup. Pelaksanaannya pun tidak boleh sembarangan, melainkan harus disesuaikan dengan perkembangan masyarakat dan prinsip-prinsip Negara Kesatuan Republik Indonesia. Selain itu, kekuasaan-kekuasaan yang menjadi isi otonomi desa pakraman tersebut pengaturannya dilakukan dalam undang-undang.

Batas-batas otonomi desa pakraman tidak diatur secara lengkap dalam Perda Desa Pakraman. Pengaturan hanya menyangkut persyaratan kekuasaan desa pakraman dalam membentuk hukumnya sendiri. Dalam pasal 11 ayat (2) ditegaskan bahwa: "Awig-awig desa pakraman tidak boleh bertentangan 
dengan agama, Pancasila, Undang-undang Dasar 1945 dan hak asasi manusia”. Persyaratan tersebut tidak hanya menyangkut norma hukumnya (awig-awig), tetapi juga berlaku terhadap pelaksanaannya, terutama dalam penerapan sanksi.. Penjelasan Pasal 11 ayat (2) menyatakan bahwa "...penerapan sanksi awig-awig tidak boleh bertentangan dengan Pancasila dan peraturan perundangundangan yang lebih tinggi”.

Campur tangan Negara terhadap awigawig desa pakraman juga dilakukan dengan mewajibkan setiap awig-awig desa pakraman dicatatatkan di Kantor Bupati/Walikota. Hal itu ditegaskan dalam Pasal 12 ayat (2) Perda Desa Pakraman. Dalam praktek, pencatatan dilakukan di Kantor Bupati/Walikota dengan menuliskan Nomor Register dan tangal pencatatan. Pada saat bersamaan dengan pencatatan tersebut, awig-awig tersebut ditandatangani oleh Bupati/Walikota dengan legal standing (kedudukan hukum) yang beragam, ada yang tertulis sebagai pihak yang "Mengetahui"20,"Murdaning Pamikukuh"21. Walaupun tidak ada penegasan tentang fungsi pencatatan tersebut, tetapi dari buku pedoman penyusunan awig-awig desa pakraman yang dikeluarkan oleh Pemerintah Daerah Provinsi Bali dapat diketahui bahwa pencatatan tersebut diwajibkan dalam rangka pengawasan dan penertiban terhadap awig-

21 Awig-awig Desa Adat Batumuulapan, Nusa Penida, Klungkung; Awig-awig Desa Adat Belega, Gianyar; Awiig-awig Desa Adat Sembung, Badung.

22 Awig-awig Desa Adat Kapal, Badung; Awig-awig Desa Pakraman Gadungan, Tabanan; awig supaya ketentuan Pasal 11 ayat (2) di atas dapat terpenuhi ${ }^{22}$.

Dari awig-awig desa pakraman yang berhasil diteliti, dapat dipastikan bahwa semua awig-awig tersebut telah dicatatkan di Kantor Bupati/Walikota Setelah dianalisis, kuat dugaan bahwa pencatatan tersebut dilakukan atas inisiatif sendiri dan dorongan kemauan dari dalm desa pakraman yang bersangkutan. Hal ini sekaligus menunjukkan bahwa walaupun desa pakramann itu otonom, tetapi tetap mengakui dan menghormati superioritas Negara (Pemerintah) Kondisi seperti ini bukan terjadi saat ini saja di jaman ketika Bali berada dalam bingkai Negara Kesatuan Republik Indonesia. Relasi desa pakraman dan Negara (penguasa) di mana desa pakraman berada pada posisi dipengaruhi atau dikuasai oleh Negara sudah terjadi sejak jaman kerajaan. Tjokorda Raka Dherana mencatat bahwa sudah sejak lama ada hubungan antara proses pembuatan awigawig dengan perkenan atau pengesahan dari penguasa daerah yang bersangktan (pungawa atau raja). Dherana menunjukkan kenyataan tersebut dengan menunjukkan beberapa contoh awig-awig desa pakraman, seperti misalnya tercantum dalam awig-awig Desa Penarukan yang diawali dengan kalimat:

22 Biro Hukum Setwilda Tingkat I Bali, 1990, Pedoman Penyusun Awig-awig, Proyek Pembinaan Terhadap Hukum Adat dalam Rangka Menunjang Pembangunan Tahun 1989/1990, hlm. 2.; Lihat juga: Biro Hukum Setda Propinsi Bali, 2001, Pedoman/Teknis Penyusunan Awig-awig dan Keputusan Desa Adat 
(UDAYANA MASTER LAW JOURNAL)

"Awignam astu nama sidam, anugrahane Ida I Gusti Anglurah Made Karangasem, kalih I Gusti Made Agung ida ica lugraha, ri satingakahe angwangun sima ika, mangda tetep terpinyane makramadesa, tur masangkepan..."23

Kutipan kalimat di atas pada intinya menyatakan bahwa pembuatan awig-awig tersebut dilakukan atas perkenan atau ijin (ica lugraha) dari pejabat negara (kerajaan) yang menguasai desa pakraman Penarukan, yaitu Ida I Gusti Anglurah Made Karangasem dan I Gusti Made Agung. Dengan demikian, secara historis dapat dilihat bahwa kondisi desa pakraman yang semi-otonom berhadapan dengan Negara sudah terjadi sejak jaman kerajaan dan dilanjutkan pada jaman kemerdekaan di bawah Negara Kesatuan Republik Indonesia.

Kenyataan bahwa otonomi desa pakraman tidak pernah steril dari pengaruh kekuasaan Negara juga dapat dilihat dari pengakuan desa pakraman terhadap dasardasar kehidupan bernegara, yaitu Pancasila, UUD 1945 dan peraturan perundangundangan lain yang relevan. Dari awig-awig desa pakraman yang berhasil diteliti, selalu ditemukan pasal (pawos) yang menegaskan hal tersebut. Bahkan, Pancasila dan UUD 1945 -yang tidak lain dari dasar negara dan hukum dasar negara - selalu diposisikan sebagai dasar (pamikukuh) dari desa pakraman itu sendiri di samping dasar lain

Tjokorda Raka Dherana, , 1995, Desa Adat dan Awigawig dalam Striktur Pemerintahan Bali, Upada Sastra, Denpasa., hlm. 131. yang tidak kalah pentingnya, yaitu agama Hindu dengan Tri Hita Karana-nya. Berikut adalah contoh pasal (pawos) yang dimuat dalam Pawos 2 Awig-awig Desa Pakraman Sangsit dauh Yeh (Buleleng), sebagai berikut.

"Desa Pakraman Sangsit Dauh Yeh ngamanggehang pamikukuh, minakadi:

a. Pancasila;

b. Undang-undang Dasar 1945;

c. Peraturan Daerah Daerah Provinsi Bali sane mamargi;

d. Tri Hita Karana manut Sada Cara Agama Hindu”

\section{SIMPULAN DAN SARAN}

\subsection{Simpulan}

Berdasarkan uraian terdahulu, akhirnya dapat ditegaskan simpulan penelitian sebagai berikut:

1. Otonomi desa pakraman adalah hak atau kekuasan desa pakraman dalam mengurus rumah tangganya sendiri. Otonomi desa pakraman meliputi seperangkat hak atau kekuasaan yang melingkupi kekuasaan-kekuasaan: (1) membentuk hukumnya sendiri; (2) melaksanakan pemerintahan sendiri; (3) melakukan pengamanan sendiri; dan (4) kekuasaan melaksanakan peradilan sendiri .

2. Otonomi desa pakraman bukanlah otonomitanpabatas, melainkandibatasi oleh syarat-syarat yang telah ditentukan Negara dalam konstitusi, yaitu harus sesuai dengan perkembangan jaman 
dan prinsip-prinsip Negara Kesatuan Republik Indonesia. Dengan demikian, sesungguhnya otonomi desa pakraman adalah otonomi yang bersifat semiotonom (semi-autonomous) dan rentan oleh pengaruh kekuasaan Negara.

\subsection{Saran}

Sebagai hasil penelitian hukum normatif, penelitian ini hanya dapat menyimpulkan lingkup isi dan batas-batas otonomi desa pakraman dari perspektif peraturan-peraturan hukum yang berlaku. Untuk dapat mengetahui lingkup isi dan batasan otonomi desa pakraman tesebut di dalam kenyataan sebagaimana dipraktekkan oleh desa-desa pakraman yang jumlahnya ribuan di Bali, maka disarankan adanya penelitian lanjutan dengan menggunakan metode penelitian hukum empiris

\section{DAFTAR PUSTAKA}

\section{A. Karya Ilmiah}

Amrah Muslimin, 1986, Aspek-aspek Hukum Otonomi Daerah, Bandung: Alumni.

Astiti Tjok Istri Putra, 2005, Pemberdayaan Awig-awig Menuju Ajeg Bali, Lembaga Dokumentasi dan Publikasi Fakultas Hukum Universitas Udayana.

Bappeda Provinsi Bali, 2014, Pedoman Diskusi KelompokMenyikapi Undangundang Nomor 6 Tahun 2014 tentang Desa yang dilaksanakan tanggal 15 April 2014.

Biro Hukum Setwilda Tingkat I Bali, 1990, Pedoman Penyusun Awig-awig,
Proyek Pembinaan Terhadap Hukum Adat dalam Rangka Menunjang Pembangunan Tahun 1989/1990.

Biro Hukum Setda Propinsi Bali, 2001, Pedoman/Teknis Penyusunan Awigawig dan Keputusan Desa Adat.

Jimly Assiddiqie, 2006, Perihal Undangundang, Konstitusi Press, Jakarta.

Marhaendra Wija Atmaja Gede, 2012, "Politik Pluralisme Hukum dalam Pengakuan Kesatuan Masyarakat Hukum Adat dengan peraturan Daerah", Disertasi, Program Doktor Ilmu Hukum Universitas Bwawijaya, Madang.

Moore Sally Falk, 1978, Laws as Process, An Anthropological Approach, Routledge \& Kegal Paul, London,Boston, Melbourne and Henly.

Panitia Ad Hoc.I DPD RI, 2009 "Naskah Akademik Rancangan Undang-undang tentang Perlindungan Masyarakat Adat", Dewan Perwakilan Daerah Republik Indonesia, Juni 2009.

Raka Dherana Tjokorda, 1995, Desa Adat dan Awig-awig dalam Striktur Pemerintahan Bali, Upada Sastra, Denpasar.

Sudantra I Ketut dan Wayan P. Windia, 2012, Sesana Prajuru Desa, Tatalaksana Pimpinan Desa Adat di Bali, Denpasar: Udayana University Press.

Sudantra I Ketut, et. all., 2013, ”Pengaturan Peradilan Adat dalam Awig-awig Desa Pakraman: Studi Pendahuluan tentang Eksistensi Peradilan Adat dalam Kesatuan Masyarakat Hukum 
Adat Desa Pakraman", Program

Studi Magister (S2) Ilmu Hukum

Pascasarjana Universitas Udayana,

Denpasar.

SukranataA.A.KetutdanAnakAgungIstriAri

Atu Dewi, 2005, "Eksistensi Pecalang

Menurut Awig-awig Desa Pakraman

(Studi Kasus Tetrhadap Awig-awig

Desa Pakraman Kedonganan, Kuta),

Pusat Studi Hukum Adat Universitas

Udayana

Tim Peneliti LBHBali, 2005, Peradilan Desa,

Alternatif Penyelesaian Sengketa,

LBH Bali-Yayasan Kemala.

Windia Wayan P., 2004, "Sesana dan Busana

Pecalang", dalam Wayan P. Windia

(ed), Pecalang Perangkat Keamanan

Desa Pakraman di Bali, Lembaga

Pengabdian Kepada Masyarakat

(LPM) Universitas Udayana.

Wirta Griadhi I Ketut, 1991, "Peranan

Otonomi Desa Adat dalam

Pembangunan", Majalah Ilmiah

Fakultas Hukum Kertha Patrika, No. 54 Tahun XVII.

\section{B. Peraturan/Putusan}

Republik Indonesia, Undang-undang Dasar

Negara Republik Indonesia Tahun 1945.

Mahkamah Konstitusi Republik Indonesia,

Putusan Perkara Nomor 007/PUU-

III/2005 dalam Perkara Pengujian

Undang-undang Republik Indonesia

Nomor 40 Tahun 2004 tentang Sistem

Jaminan Sosial Nasional terhadap
Undang-Undang Dasar Negara

Republik Indonesia Tahun 1945, ducapkan pada tanggal 18 Agustus 2005

Pemerintah Daerah Provinsi Bali, Peraturan Daerah Prpvinsi Bali Nomor 3 Tahun 2001 tentang Desa Pakraman

Awig-awig Desa Pakraman Koleksi Pribadi I Ketut Sudantra: (1) Awig-awig Desa Adat Mengwi, Badung; (2) Awigawig Desa Adat Sembung, Badung; (3) Awig-awig Desa Adat Kapal, Badung; (4) Awig-awig Desa Adat Yeh Buah, Jembrana; (5) Awig-awig Desa Adat Batumulapan, Nusa Penida, Klungkung; (6) Awig-awig Desa Adat Bugbug, Karangasem; (7) Awig-awig Desa Adat Gebog Satak Tiga Buungan, Bangli; (8) Awig-awig Desa Adat Belega, Gianyar; (9) Awig-awig Desa Pakraman Gadungan, Tabanan; (10) Awig-awig Desa Pakraman Sangsit Dauh Yeh, Buleleng.

Pararem Pacalang Koleksi Pribadi I Ketut Sudantra: (1) Pararem Desa Pakraman Jimbaran Indik Pecalang; (2) Pararem Desa Pakraman Pecatu Pecalang; (3) Pararem Desa Pakraman Unggasan indik Pecalang; (4) Parerem Desa Pakraman Kapal indik Pecalang. 